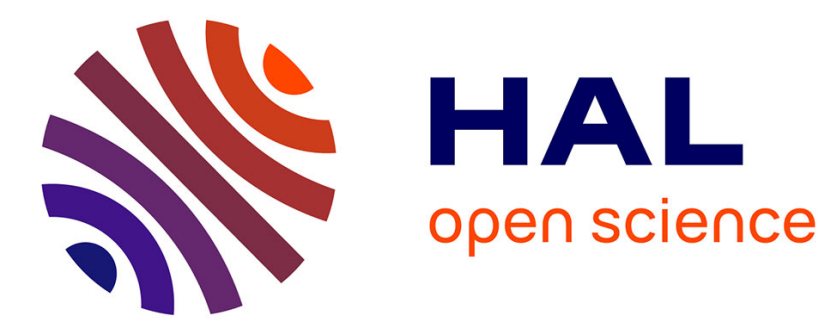

\title{
Identity, Nationalism and Anthropologists
}

Maria Couroucli

\section{To cite this version:}

Maria Couroucli. Identity, Nationalism and Anthropologists. Paul Sant Cassia. Between Europe and the Mediterranean, Palgrave Macmillan, pp.73-87, 2007. halshs-00353307

\section{HAL Id: halshs-00353307 https://shs.hal.science/halshs-00353307}

Submitted on 15 Jan 2009

HAL is a multi-disciplinary open access archive for the deposit and dissemination of scientific research documents, whether they are published or not. The documents may come from teaching and research institutions in France or abroad, or from public or private research centers.
L'archive ouverte pluridisciplinaire HAL, est destinée au dépôt et à la diffusion de documents scientifiques de niveau recherche, publiés ou non, émanant des établissements d'enseignement et de recherche français ou étrangers, des laboratoires publics ou privés. 


\title{
Identity, nationalism and anthropologists
}

\author{
in Sant Cassia P. (ed), Between Europe and the Mediterranean, London, \\ Palgrave Macmillan, 2007. pp. 73-87.
}

\section{East meets West?}

This paper is about the ambiguous relationships between Europe and the Mediterranean as they materialize in the anthropological studies on modern Greece. The European enlargement of 2004 incorporated into the Union countries that once belonged to the Soviet block, and more anciently to the Russian or Austro-Hungarian Empire. Europe goes East, but not towards the Orient: Turkey is knocking at the door and most Balkan countries remain prospective candidates. This is a changing landscape where member states and aspiring states negotiate their relative positions and the divide West/Rest, i.e. West=us, Orient=them organizes the latest inclusions and exclusions. In the South-Eastern Europe and the Balkans, the divide separates Europe from the Ottoman lands, along the frontier where the two worlds fought each other from the $15^{\text {th }}$ until the $19^{\text {th }}$ centuries.

Since the publication of Said's Orientalism (1978) the question of Western identity and the definition of the Other -the Oriental- has been very much debated un anthropology. Said's criticism of the image of the Orient insists on the radical opposition between West and Rest and also on the timeless essentialism of the Orient: J. Carrier (1992) has shown how anthropology cannot get away from this essentialism, so that even when studying the western world "the Other expands to include most people in western societies, people who, after all, are not middle-class academics" (1992:188). He reminds his reader that anthropologists working in western societies are trained in the same way as classic anthropologists, they're out to study the exotic and that in this way anthropologists essentialize the two categories, the West and the Others, so as to arrive at an exaggerated sense of difference (ibid, p. 203). It has also been pointed out that 'native anthropology' is a contradiction in terms but also that anthropological understanding may be inadequate, because it is impossible to speak both from a native and from an anthropologist's position (Hastrup, 1995: 148-159, Madianou 1993). The problem of anthropological understanding had also to do with the uneasy relations between anthropology and history, both as regards relations to time and as regards relations to historical research producing new knowledge about societies studied by ethnographers.

One of the many examples is the Greek case, where anthropology had stayed away both from social time and from historical and political science research within the country and has found itself more or less isolated from local intelligentsia. One should argue that this is due to a difference between the native and the non-native points of view and that this difference is itself a result of the post WWII world order, where the 'western' model dominates unhindered in the 'free world', creating inequalities between the center and the periphery (Argyrou, 2002).

The anthropology of Greece is a relatively important field in the Anglo-American anthropological literature, with more than 50 books published since the 1960's. Indeed, postwar Greece can be described as an anthropologist's Eden: the only south-eastern European country outside the communist block, the only Balkan state to have joined the EU (since 1981), Greek society is both familiar and exotic, part of Europe but also marginal to it (Herzfeld, 1987). In the last 20 years Greek anthropology has established itself in Greece, 
where two university departments are thriving. These recent developments have induced changes in fieldwork methods, choice of research subjects and use of analytical categories (Madianou 1993, Papataxiarchis 2005).

\section{Nationalism: ambiguities and questionings}

Nationalism and national identity are among those analytical categories that have been redefined in late years through ethnographic analysis. It is also an area where fieldwork is most obviously dependent upon the conditions of study and the interaction between foreign observer and native observed, who find themselves in structurally opposed positions, in Greece as elsewhere. And, one may add, all the more so when political conditions in the country under study are not optimum conditions of democratic rule, as was the case in Greece during the military regime of 1967-1974 when civil rights and freedom of expression were not fully enjoyed by citizens ${ }^{1}$. This crucial dimension of modern Greek society has been largely ignored in anthropological writings, not only because historical research on the question until the late 1990s was very limited, but also because of the mutual ignorance which characterizes the relations between anthropologists and historians working on Greece ${ }^{2}$.

Today, categories such as nationalism, national ideology or ethnic identity have been largely questioned after having been present in most debates in the fields of both political science and anthropology in the 1980s and 1990s. The historical context of the debates concerning south-eastern Europe is of course the cold war period, the collapse of the communist world and its subsequent division into smaller 'nations' aspiring to independent states. In Greece, the military regime and its 'Christian-Hellenic' ideology (the colonels' slogan was: Greece of Christian Greeks) had triggered a long process of rethinking notions like fatherland (patridha), nation (ethnos) or Hellenism (ellinismos) among historians and more widely among social scientists ${ }^{3}$. More recently, the Yugoslav war, often presented as a sudden burst of violence following the fall of Berlin's wall, shook apart many firm beliefs about ethnic identities and the reality of nation-states among Balkan specialists provoking a re-consideration of the categories involved in anthropological and sociological analyses ${ }^{4}$.

Fieldwork conditions have always been considered of crucial importance for the anthropologist, especially when the themes of the study include national or collective identity, ethnicity, minorities and the like. Yet, although the 'reflexive' tendency is certainly there in Greek anthropology, few deal with the subject directly. Margaret Kenna, who addressed the issue thirty years after her first fieldwork in Anafi -a small island which served more than once as an exile camp - is an interesting exception illustrating the importance of fieldwork conditions for subsequent anthropological analysis to which I will come to later in this paper.

\footnotetext{
1 This seems to characterize post-war Greek society more generally, Cf. Mazower, Mark, After the War was Over, Reconstructing the family, nation and the state in Greece, 1943-1960, Princeton University Press, 2000.

${ }^{2}$ This is not true within Greece, where anthropologists and historians work together on a regular basis.

${ }^{3}$ Cf. Maria Couroucli 2002, 2003

${ }^{4}$ Cf. Jane Cowan and K.S. Brown (eds), The politics of identity and difference, London, Pluto Press, 2002; Xavier Bougarel, Balkanologie, Maria Todorova, Imagining the Balkans, Mark Mazower, the Balkans.
} 


\section{Anthropology in Greece}

Anthropologists arrive in Greece after WWII, pretty much at the same time as the first foreign tourists. Both groups are visibly educated, belong to one of the great western nations and are often linked to the foreign institutes in Athens that usually host archaeologists working in the country: the British, the American, the French schools. One should add that until the late 1980s anthropology was very much a rural practice, so that the anthropologist was more urban and "learned" than the village people he or she studied ${ }^{5}$.

Village ethnographies published during this period follow the general trends of the time, focusing on the local and the synchronic and making little case of the conditions of the exchange between observers and observed and even less of the difficulties of comprehending categories and their use according to context. Questions related to interpretative anthropology, to the anthropologist's work in terms of history and memory (Geertz 1983, Marcus, 1968) or to native versus non-native anthropology (Hastrup, 1993) have not yet been addressed especially in relation to the more recent post-colonial analyses which have questioned the 'objectivity' of anthropological representations, stressing the fact that they are themselves part of a given and dominant culture (Argyrou, 2000, Herzfeld, 2002)

In Greece, observers and observed seem to be both culturally and socially distant, yet the separation between the two worlds is not as clear as elsewhere. Skopetea (1992) has pointed out how Greece, by the very fact of being marginal to Europe, was also part of it during the emergence of collective identities (European, Ottoman, Balkan, Greek) in the $19^{\text {th }}$ and $20^{\text {th }}$ centuries. The 'European' category included part of the urban populations of the Ottoman Empire in the same way as it later included the national elites of the Balkan countries precisely because the 'West' was in fact present within Ottoman society. Skopetea asserts that the West is in the East, i.e. the West defines itself and becomes West by opposition to the East and in relation to it; "the West is here", she writes, meaning inside the Empire. In her study of women's education in the $19^{\text {th }}$ century, Bakalaki (1994) also points out that Greece was in several ways part of Europe well before joining the EC in 1981. She analyzes the influence of urban elites, who had adopted western lifestyles, upon rural populations and she also criticizes the ethnographers' naïve assumption that rural lifestyles of the $19^{\text {th }}$ century have survived until the ethnographer's fieldwork in the second part of the $20^{\text {th }}$ century. In her view, the populations studied by ethnographers do consider that in many ways they live in the same world as Europeans. One can therefore assume that members of rural communities studied by xenoi (foreigners) thought they all belonged to the same hierarchical system, which included both local society and the global world, inside a familiar -and dominant- model where western society occupies the top of the pyramid, while Other societies dwell in the inferior apartments, according to their closeness to the dominant pattern.

\section{Fieldwork}

Anthropologists have always maintained that long fieldwork is more profitable, because it allows the ethnographer to establish a relationship of mutual trust between himself and the people observed, this making the observation more accurate. Experience has shown that informants' narratives vary according to circumstances and that the patient ethnographer will finally get a more interesting version of events that the hastier surveyor. Yet, even after a long

\footnotetext{
${ }^{5}$ In the late 1980s an important change occurred, as local anthropologists trained abroad, mainly in Britain or the US, sometimes in France, come back to Greece. They form a small but important anthropological community, mainly in Athens and Mytilini, around two new departments of anthropology.
} 
and patient fieldwork, one cannot assume that the structural oppositions at work in the relation between the two parties can be annihilated. The anthropologist who may become 'one of us' during his fieldwork does not in fact become part of the society under study; as an ethnographer he needs to maintain some distance in order to observe, thus occupying an ambiguous position, more outside than inside. Native anthropology, although criticizing foreign anthropologists' misunderstandings, has not proposed as yet new fieldwork rules and practices (Jackson, 1987, Loizos, 1992, Argyrou, 2000).

Although the native's point of view is impossible to apprehend, one may try to understand the social interaction involved during fieldwork (Goffman 1967). One may assume that when a 'foreigner' enters a conversation in a Greek village coffee-shop the exchange will be determined by the mutual understanding of the categories in use, for example each other's identity and social status ${ }^{7}$. Jacques Lacarrière has described the first exchange between a local and a foreigner in Crete as the 'hospitality ritual'. The interaction between the host and the guest consisting of conventional questions and answers which inform about segmentary oppositions at work and end up in the negotiation of each other's status: "Where do you come from? France, Germany, England, America? Then: how old are you? Are you married? Do you have children? Are your parents still alive? What is your profession? ... Then comes 'the ultimate question': 'do you like Greece?' After which, one starts relating his travels, talk about Paris or, even better, about politics" (Lacarrière 1975:126).

The segmentary principle is here at work in much the same way as among the Nuer of the Sudan: people identify with larger and larger groups the further up they go into the generations and common ancestry: brother is closer to cousin, who is closer to co-villager, who is closer to fellow-countryman ${ }^{8}$. In the case of the Cretan villager welcoming Lacarrière or Herzfeld, for example, later, it is the Greek welcoming the foreigner which are the categories concerned in the first place; the separation of identities taking place at the national level. One may here assume that during interaction the parties take this 'maximal' distance into account.

It is plausible that the first encounters between the anthropologist and the people observed take place along similar lines, i.e. that the exchanged information about each other's identity is part of the first meetings. We may also assume that the fieldworker being a foreigner, in most cases, the answers to the questions he asks would take into account his 'foreignness', i.e. his assumed ignorance of the national society. In fact, we're also within the hospitality sphere and rules, one of which being that the guest, when in the master's house, must abide by the rules of the house. The ethnographer does the same: if he is to continue his fieldwork, he must become the guest of the local community under study and act according to its rules of hospitality ${ }^{9}$.

In 1960's Greece, the military coup and its social consequences have certainly played an important role in the way a 'foreigner' -anthropologist or not- was perceived. More generally, the Greek examples tend to show that contextualizing contemporary ethnographies within historical space-time can shed more light on the question of the relations between observer

\footnotetext{
${ }^{7}$ One may look at the encounter between anthropologist and people observed along Goffman's analysis: When an individual appears before others, he knowingly and unwittingly projects a definition of the situation of which a conception of himself is an important part (The presentation of self in everyday life 1959:242)... The individual tends to treat the others present on the basis of the impression they give now about the past and the future. It is here that communicative acts are translated into moral ones. (ibid., 249).

${ }^{8}$ Cf. Evans-Pritchard on the segmentary principle and the opposition between segments which regulates the political relations and conflicts among the Nuer: "The members of any segment unite for war against adjacent segments of the same order and unite with these adjacent segments against larger sections" (1940/1968:142).

${ }^{9}$ Cf. Julian Pitt-Rivers, The fate of Shechem of the Politics of Sex, Essays in the anthropology of the Mediterranean, CUP, 1977.
} 
and observed. It is useful to remember that during the military regime (1967-1974) the country was ruled by martial law that limited freedom of expression and abolished the right to vote for all citizens ${ }^{10}$. One may add that the presence of foreigners -free citizens in their own countries- among the local population living under martial law and experiencing repressive politics may lead to some tension and ambiguity. The lack of equality of status vis-à-vis the authorities - a disparity of social rights reminiscent of colonial situations between natives and westerners - and the humiliation of having to admit the obvious fact that the country was drifting away from western society under this regime complicated the relationships between Greeks and non-Greeks. Finally, it is useful to remember that those resisting the regime presented themselves as patriots defending national dignity, while the junta's rhetoric was nationalistic, anti-communist, full of stereotypes on Greek history and identity; hence studying nationalist representations of cultural, social or political Greek identity in the period 1960-1990 can prove to be a complex and difficult endeavour.

A characteristic case briefly mentioned above is Anafi, an island that served more than once as an exile camp for political prisoners, and also the island where the then young anthropologist Margaret Kenna conducted her fieldwork in 1966-67. Many years later, in 2001, she published a book on her fieldwork, a reflection on the relation between the anthropologist and his/her field, including a detailed account of her experience of the military coup in April 1967 while she was on the island. In a retrospective analysis of the event, Kenna reflects on the reasons she was in fact unable to properly research the island's recent history:

I became conscious that, for the islanders, trying to turn my attention away from the present and the recent past to the more distant past was a strategy to keep me away from the sensitive contemporary issues. ... the history of Anafi to which I was encouraged to turn, however, was an uncontentious past; mythical Anafi revealed to Jason and the Argonauts by Apollo; classical Anafi ... Venetian Anafi ... patriotic Anafi (1821), ... post-Independence Anafi, sending its young men to help build King Otto's palace. ... I was too naïve to understand why Anafiots would not freely answer questions about those (more recent) times. If I had thought about my own experience, as a six-year old Australian 'alien' in Berkeley, California, in the McCarthy Era, hearing my parents talking of the Loyalty Oath, I might have understood a little better (2001:148).

The ethnographer was in this case not only ill prepared to take history into consideration, but also not welcomed to do so by the local community, who feared that this could mean trouble for them.

A much more recent case is Anastasia Karakasidou's work on the town of Assiros/Guvezna in Greek Macedonia in the 1990s, a further example of the inherent tensions between ethnography and politics: the ethnographer was harassed in Greece and abandoned by her English publisher, because her work was taken to be 'anti-Greek', i.e. not patriotic enough ${ }^{11}$.

\footnotetext{
${ }^{10}$ The regime had imprisoned and sent to exile thousands of people without trial, accused of being political opponents, often on the basis of some local police report. Authorities were particularly repressive in villages and urban neighborhoods who had voted for the center or left parties during the previous election; in the same spirit, villagers with no electricity were promised to be connected if they voted $100 \%$ yes in the one referendum organized by the military junta in 1973 . One needed to first obtain from the local police a 'certificate of social beliefs' (that is of anti-communist opinion), before one applied for a driving license or a passport. The numerous civil servants who failed to obtain such a document were simply sacked from their jobs, and this is how universities were stripped of their professors during this time. Greeks abroad organized meetings and protests against the regime, including campaigns against tourism in Greece. This is why many intellectuals in the opposition considered foreign students who went to Greece at the time (with or without scholarships from the Greek government) as de facto collaborators of the regime. Cf. Clogg and Yannopoulos (eds), Greece under military rule, London, Secker and Warburg, 1972, who estimate the political prisoners of the year 1967 as 4567.

${ }^{11}$ Cf. the Karakasidou affair, which is related to the early 1990's Macedonian question in Greece, http://www.hnet.msu.edu/ sae/threads/CUP/protst.html and http://members.tripod.com/giorgi10/id52.htm.
} 
The book is a historical anthropological monograph based on a variety or sources: local legends recorded in the field, local archival material, recent historical research and national ideology in its different forms (school books, political rhetoric). The author distinguishes three types of historical narratives on the local level: the 'generic' national history taught at school as a series of events (Turkish oppressive rule, Bulgarian aggression, anti-communist struggle) constitutes the first kind. The second narrative links local events and landmarks to the grand national heritage; the third kind, not considered 'history' by locals, refers to the past through personal and family experiences. These family histories, though they might refer to non-Greek-speaking ancestors migrating to the area in the 1860's -and thus clash with the standardized national narrative that does not acknowledge the presence of non-Greek speakers among the Greek population- are oddly not considered by the locals to be anomalous vis-à-vis national history learned at school and celebrated on national holidays (1997:223).

\section{From diglosia to split thinking}

Anthropologists studying representations of Greek national identity have often pointed to a structural opposition, a dual model of identification. On the one hand, vernacular, familiar, popular (Romeic) Greece, close to traditional society with links to the ottoman past; on the other hand Hellenic Greece, official, cultured, urban, close to the West. The analysis corresponds to the classical opposition elite/lower classes found in historical literature. For political scientists, this duality represents two distinct social groups: those of rural origin constitute the first group, the second being the urbanites, originating from the Greek urban elite of the Balkan and Anatolian cities. The cultural expressions of these two groups have been labelled underdog culture and reformist culture respectively (Diamantouros, 1994); the same kind of duality has been identified as an opposition between the language of the people and that of the State (Herzfeld, 1982, Couroucli, 1991, 1995) ${ }^{12}$. Herzfeld's work deals more than once with the representations of Greek national identity and the coexistence of two models, the one referring to intimate Greece, synonymous with tradition and Ottoman legacy, the other being the official Hellenic model that claims direct descent from classical antiquity and at the same time justifies the existence of a Greek Nation-State among other European nation-states. Herzfeld criticizes top-down analyses of nationalism and the nation-state and their inability to take into consideration the "rueful self-recognition" the anthropologist is able to observe during his long-term fieldwork; he also calls this duality disemia, that is "a formal tension between official self-presentation and what goes on in the privacy of collective introspection" and proposes the concept of cultural intimacy: national identity would then be a mixture of embarrassment and idealized virtues (1997: 6-14) ${ }^{13}$.

Bakalaki (1994) has observed that anthropologists' analyses imply a "problematic isomorphism between $19^{\text {th }}$ century rural attitudes and those encountered by ethnographers working in Greece after the 1960s". In fact, she claims, the two models are not at all equivalent, since the Hellenic (modern) discourse dominates over the Romeic (traditional) in modern Greek society. The two parts of the duality being unequally represented in everyday exchanges, some of the elements observed may be present as verbal and behavioural

\footnotetext{
${ }^{12}$ M. Herzfeld, Ours once more, Folklore, Ideology and the making of Modern Greece, Uiv. Of Taxas Press, 1982; M. Courouli, "Diglossie et double langage : langues et langages d'honneur en Grèce", Langage et société , 57, 1991,p. 71-92; and "Le lalein et le grafein, parler et écrire en grec" in Oral et ecrit dans le monde turco-ottoman, Revue du Monde Musulman et de la Méditerranée (REMMM) no 75-76, 1995/1-2, pp. 257-271.

13 "If the nation is credibly represented as a family, people are loyal to it because they know that families are flawed -that is part of love- and so they rally to the defense of its compromising but warmly familiar intimacy" (1997:172).
} 
stereotypes rather than as usable analytical categories for the social scientist. Duality then seems to be closer to sociological imagination, a pitfall that foreign analysts seem to have more trouble to avoid ${ }^{14}$.

The diverging interpretations of local or national 'representations' are indeed one aspect of the question of how ethnographic research may be related to historical and political science research. I have mentioned above that anthropological work has failed to take into account one major opposition characteristic of $20^{\text {th }}$ century Greek society, between "those who think nationally", the ethnikofrones, and the others, considered as enemies of the authorities. This dualism corresponds to a greater or lesser extent to the division left/right and has been at work for the best part of the century, from the early 1930s until today; among its latest manifestations, those triggered by the publication of Karakasidou's monograph that Cambridge University Press decided not to publish in the early $1990 \mathrm{~s}^{15}$.

I think that the dual model had persisted among students of Greek society because the basis on which it stands is still there: first, the synchronic character of the great majority of anthropological analyses which, ignoring history, reinforce the a-temporal aspect of the phenomena under study, as if these have always belonged to the society under study. This kind of reasoning reached its climax during the ex-Yugoslavia crisis: the Balkans, one could read in the western press, is a traditionally violent region, ethnic conflicts are endemic; therefore it is not necessary to look for the causes or the forms of inter-ethnic violence because these are quasi-natura ${ }^{16}$. It is possible that behind anthropologists' hesitation to tackle the political side of social phenomena in Greece lays some uneasiness about the junta years. The opposition Greek/foreigner cannot be fully understood without reference to its special dimension during this period; as was mentioned earlier, it symbolized the separation of those who had a right to enjoy democracy (the foreign observers, journalists, anthropologists among them) and those natives living inside the country who were denied freedom and civil rights in the name of the balance of power and world peace during the cold war.

The ethnography of Greece brings out problems of method related to cultural distance between observer and observed in a context where this distance is less explicit. While many have studied the paradox of Greece's incomplete inclusion in the West, the opposite question has not been dealt with: is the 'western' ethnographer 'at home' in Greece? How is one to define what distinguishes the ethnographer's world from the world where the observed belong? Although one knows that each party's status influences the content of the discourse, i.e. while it is generally accepted that status differences (i.e. social, cultural or political distance between observer and observed) do in part determine the content of the exchange, yet this fact remains very much implicit in anthropologists' analyses of discourses on local identities. Some of the complexities of fieldwork may be revealed by contextualizing within the social space-time of the study, by analyzing the ways foreign ethnographers are perceived in comparison to local ethnographers, how their respective identities are being determined in relation to complex and changing factors, varying with time, even within a single stay ${ }^{17}$.

\footnotetext{
${ }^{14}$ It is noteworthy that the 'dual' analysis is based more on the national narrative found in rather old (pre-1970s) historical and folklore works and relies much less on work published locally in the last twenty years. More about the role of the military regime's ideology (1967-74) in transforming later nationalist representations and historian's production, Cf. Couroucli, 2002.

${ }^{15}$ On the history of institutions and anti-communist legislation, cf. Alivizatos; on Modern Greek history cf Campbell \& Sherard (1968), Svoronos, Clogg a and b, Buschotten.

${ }^{16}$ For a critical analysis of these Cf Cowan, 2000.

${ }^{17}$ Cf. for example, Kenna, 2001, and also James Faubion (Modern Greek Lessons, 1993) on these questions, even if the argument is less explicit, he insists on the ambiguity between the western world and the local society in his study of Athenian intellectuals. His book received a scathing review in a Greek newspaper pointing out the very many factual errors and suggesting that the author should have written a travel book instead of a book of anthropology. (REF)
} 


\section{The West as looking-glass}

The term disemia (Herzfeld, 1997) mirrors diglosia, a term coined by Ferguson to analyze similar linguistic phenomena in Greece, in the Arab world, and among the Creole speaking societies, i.e. the double language structure, where one is linked to the high culture, the one closer to the West via history and the other to popular culture, the most distant from Western culture. This paradigm sums up the way anthropologists (western, by the way) have analyzed the less exotic societies and the Mediterranean in particular: neither primitive nor civilized, with a glorious past and a miserable present. The paradigm is the expression of the traditionally western point of view, the implicit model against which, as with Procruste's bed, the Others are being measured; as Herodotus and Marco Polo did before modern travellers and anthropologists. Is it possible, then, that the concept of disemia is "good for the West"? that it is addressed to the foreigner, in his own terms, those of the opposition between the incomplete local and the universal ideal of humanity?

Today its seems that the western model is no longer considered as "good to copy" by the "almost western" societies; their elites -westernized or not- questioning its uniqueness and its superiority. Carrier argues, for example, that anthropological research, which traditionally sought out the alien and the exotic, has become less possible and less necessary because of "political changes in the third world, economic changes in western universities and intellectual changes in anthropology" (1992:195). Moreover, as anthropology moves from the exotic towards the urban field, questions of fieldwork methods are being reconsidered and Goffman's warning that "the observer's need to rely on representations of things itself creates the possibility of misrepresentation" (ibid, p. 251) is useful to remember in this discussion.

I have tried, through the Greek example, to highlight the implicit but inevitable comparison West/East, whatever this East may be, as long as it acts as a mirror of Us in ethnographic work $^{18}$. I should add that the usefulness of oppositions is relative. Apart from the opposition local/global, which establishes an inequality of scale, the other couples are, in the last analysis, only conventions.

It is, of course, impossible to avoid all ethnocentric analyses, but one must also be able to avoid sweeping generalizations stemming from largely ancient and unconscious constructions, and question Occidentalism and its implications. It is vain to think that one may get completely rid of one's cultural point of view; but one may instead try to analyze the intricate relations between observers and observed, especially when these belong to two different worlds. For example, in the $19^{\text {th }}$ century Ottoman society, the West intervened through its missions and observed through its journalists (Skopetea 1992). The role of these early reporters is important, in so far as they depicted the ottoman society in their writings and influenced western countries' public opinions. They made frequent references to the 'barbarian' character of the Balkan peoples, regularly allotting them a specific place along the scale of civilization, changing their relative positions according to current events. In these cases, "the westerner, whatever his nationality or his political party, represents himself by an abstraction, 'the West', and believes that he belongs to an ideal society that, ungracefully, immoderately, hopelessly sometimes, Ottomans and Balkan people try to imitate" (Skopetea, 1992:68).

\footnotetext{
${ }^{18}$ Note the very interesting choice of the title of the first French monograph on Greece: La violence et la ruse (Violence and slyness, M.E. Handman, 1984), a phrase Hegel used to characterize the state of nature as opposed to human society, Cf. Jacqueline Russ, Les chemins de la pensée, Paris, Bordas, 1999, p. 331.
} 
Behind the ethnographic endeavour lies the same kind of abstraction; the point of view of the ethnographer relies on a particular representation of "the West" which can produce absurd comparisons: the Chinese, African or Mediterranean farmer or fisherman is measured against the liberal intellectual living in European capitals or American university campuses. The comparison is not between communities of fishermen, say, of East and West, but between Mediterranean fishermen, for example, and "the West". Moreover, a 'western' observer, for example, would convincingly argue that fishing communities are not 'typical' of English or French society, while anthropologists do not hesitate to generalize on other cultures from fieldwork conducted in marginal communities. It is clear that as long as the western model remains dominant, those at the periphery also adopt the centre's point of view ${ }^{19}$.

The anthropological production on Greece can be a useful starting point for the investigation of the relation between the ethnographer and his/her field, especially when the relationship involves separate identities. For example, the fact that a 'foreign' and a 'native' observer may be perceived in quite different ways, especially when he/she asks questions relating to identity needs further analysis ${ }^{20}$. The ambiguous position of the guest renders the analysis of these categories even more challenging: for if one is to get interesting answers one has of course to ask interesting questions. The quality of which, as we have seen, does not only depend on how knowledgeable one is not only about anthropology but also about local and national social and political history; in other words, one cannot get away without contextualizing ethnographic enquiry.

Paris, January 2005

\section{MARIA COUROUCLI : REFERENCES}

ALIVIZATOS, Nicolas, "Nation» contre «Peuple» après 1940, in Tsaousis, D. (ed), Hellinismos kai Hellinikotita, Athènes, Hestia, 1983.

ARGYROU, Vassos, Anthropology and the will to meaning, A post-colonial critique, London, Pluto Press, 2002.

BAKALAKI, Alexandra, "Gender-related discourses and representations of cultural specificity in nineteenth century and twentieth century Greece", Journal of Modern Greek Studies, 12, 1994.

BOURGOIS, Philippe, "Confronting the ethics of ethnography: lessons from fieldwork in central America", in Harrison F.V (ed), Decolonizing anthropology, Association of Black Anthropologists, AAA, Washington DC, 1991.

CAMPBELL, John and SHERARD, Philip, Modern Greece, London, Ernest Benn Ltd, 1968. CARRIER, James, "Occidentalism, the world turned upside-down", American Ethnologist 19, 1992.

\footnotetext{
${ }^{19}$ It has been argued about those peripheral elites that while identification with Europe may generate both pride and humiliation (because unattainable) "the pride generated by an emphasis on difference may also result from the internalization of a 'European' fascination with the exotic" (Bakalaki, 1994:101) Cf. also Herzfeld 1997: 89-106.

${ }^{20} \mathrm{Cf}$ Karakasidou's discussion on this in the afterword of her monograph, Herzfeld's discussion of the Rhodian police attitude during his short stay on the island. One last, personal, remark: while on the field in Corfu in 1977-78 (Cf. Couroucli, 1985) none of the people I worked with had the idea to inform me about Greek national history. My identity, a native with university education was one probable reason, the other being that during my stay no political crisis prompted any inquiry about these matters. One of my oldest and better educated informants had pointed out my status in his eyes by addressing me in official Greek (kathareuoussa), that being the appropriate language to address members of the learned elite and authorities in general.
} 
CLOGG, Richard and YANNOPOULOS, George, (eds), Greece under military rule, London, Secker and Warburg, 1972.

CLOGG, Richard, A Concise History of Greece, Cambridge University Press, 1992.

COMAROFF, John and Jean, Ethnography and the Historical Imagination, Boulder, Westview Press, 1992.

COUROUCLI, Maria, Les oliviers du lignage, Paris, Maisonneuve et Larose, 1985,

COUROUCLI Maria, Le nationalisme d'Etat en Grèce, in A. Dieckhoff et R. Kastoriano (eds), Nationalismes en mutation en Méditerranée orientale, CNRS editions, 2002.

COUROUCLI, Maria, Heroes and their Shadows, the hungry, the humble and the powerful, Journal of Mediterranean Studies, vol. 3, no 1, 1993.

COUROUCLI, Maria, "Genos, ethnos, Nation et Etat-nation", Ateliers, XXV, 2003

COWAN, Jane et BROWN, K.S. (eds), 'Macedonian inflections', in Macedonia, The politics of identity and difference, London, Pluto Press, 2002

DIAMANTOUROS, Nikiforos, Cultural Dualism and Political Change in Postauthoritarian Greece, Madrid, Centro de Estudios Avanzados en Ciencias Sociales, Instituto Juan March de Estudios e Investigationes, 1994; Greek edition: Politismikos Diismos kai politiki allagi stin Ellada tis metapoliteusis, Athènes, Alexandria, 2000.

EVANS-PRITCHARD, The Nuer, OUP, 1940.

FAUBION , James, Modern Greek Lessons, a primer in historical constructivism, Princeton Universsity Press, 1993.

FERGUSON, C.A., Diglossia, Word, 15,1, 1959

GEERTZ, Clifford, Local Knowledge, Further Essays in Interpretative Anthropology, Basic Books Inc., 1983

GEFOU-MADIANOU, Dimitra: "Mirroring ourselves through western texts: the limits of an indigenous anthropology", in Driessen, Henk (ed) The Politics of Ethnographic Reading and Writing, confrontations of western and indigenous views, Verlag brietenbach publishers, Saarbrücken, 1993.pp. 160-181

GOFFMAN, Erving, Interaction ritual, Essays in face-to-face behavior, Pantheon Books, NY, 1967.

GOSSIAUX, J-F, Pouvoirs ethniques dans les Balkans, Paris, PUF, 2002.

HANDMAN Marie-Elisabeth, La violence et la ruse, Edisud, 1985.

HASTRUP, Kirsten, "The native voice - and the anthropological vision", Social Anthropology, 1993, 1, 2, 173-186.

HASTRUP, Kirsten, A passage to anthropology, between experience and theory, London, Routledge, 1995

HERZFELD, Michael, Portrait of a Greek imagination, Chicago, 1997.

HERZFELD, Michael, Anthropology through the looking-glass, CUP, 1987.

HERZFELD, Michael, Cultural Intimacy, Social Poetics in the Nation-State, New York, Routledge, 1997

HERZFELD, Michael, Ours Once More, Folklore, Ideology and the making of Modern Greece, University of Texas Press, 1982.

JACKSON, A (ed) Anthropology at Home, London, Tavistock, 1987

Journal of Modern Greek Studies, Vol.14 no 2, October 1996, Special issue: Macedonia.

KAPLAN, Martha, "Meaning, agency and colonial history: Navosavakadua and the Tuka movement in Fiji", American Ethnologist c. 1990

KARAKASIDOU, Anastasia, Fields of Wheat, Hills of Blood: passages to nationhood in Greek Macedonia, 1870-1990, Chicago, University of Chicago Press, 1997.

KENNA, Margaret, Greek island life: Fieldwork on Anafi, Harwood Academic, 2001

KEELY, Edmund, Inventing Paradise, The Greek journey 1937-47, Northwestern University Press, Evanston, Illinois, 1999. 
KOVATS-BERNAT Christopher J., "Negotiating dangerous fields: pragmatic strategies for fieldwork amid violence and terror", AA, 104(1):208-222, 2002

LACARRIERE, Jacques, L'été grec, Paris, Plon, 1975.

LAIDLAW, James, "For an Anthropology of ethics and freedom", JRAI, 8, 311-332, 2002

LOIZOS, P. 1992 "User-friendly ethnography?" In JH. De Pina-Cabral and J. Campbell (eds) Europe observed, London, Macmillan, Oxford, St Anthony's.

MARCUS George, E., Ethnography through thick and thin, Princeton University Press, Princeton, New Jersey, 1998.

MAZOWER, Mark, After the War was Over, Reconstructing the family, nation and state in Greece, 1943-1960, Princeton University Press, 2000.

NUGENT, Stephen, "Anthropology and public culture; the Yanomami, science and ethics", Anthropology today, vol 17 no 3, 2001.

ORTNER Sherry, B. "Resistance and the problem of ethnographic refusal", in Fox, R.G (ed), Recapturing anthropology: Working in the present, Santa Fe, 1991.

PITT-RIVERS, Julian, "La loi de l'hospitalité", in Anthropologie de l'Honneur, Le Sycomore, 1983, pp. 149-176.

PRICE, David, "Lessons from Second World War anthropology, peripheral, persuasive and ignored contributions", Anthropology today vol. 18, no 3, 2002.

ROWBOTHAN Don, "Postcolonialités: le défi des nouvelles modernités", Revue Internationale des Sciences Sociales (UNESCO) 153, 393-408, 1997

RUSS, Jacqueline, Les chemins de la pensée, Paris, Bordas, 1999.

SKOPETEA, Elli, I Disi tis Anatolis, (The sunset of dawn, Images from the end of the Ottoman Empire), Athens Gnosi, 1992.

TODOROVA, Maria, Imagining the Balkans, Oxford University Press, 1997

TODOROVA, Maria, "The Course and Discourses of Bulgarian Nationalism", in P. Sugar (ed.) Eastern European Nationalism, American University Press, 1995.

VAN BOSECHOTEN, R. From Armatolik to People's Rule. Investigation into the Collective Memory of Rural Greece, 1750-1949, Amsterdam, Hakkert. 